\title{
Analisis Kompetensi Berbicara Anak Usia Dini pada Masa New Normal
}

\author{
Siti Nur Hayati ${ }^{\boxplus}{ }^{凶} \mathbf{N a}^{\prime}$ imah $^{1}$ \\ Pendidikan Islam Anak Usia Dini, Universitas Islam Negeri Sunan Kalijaga Yogyakarta, \\ Indonesia ${ }^{(1)}$ \\ DOI: $10.31004 /$ obsesi.v6i4.2107
}

\begin{abstract}
Abstrak
Kompetensi berbicara anak usia dini pada masa new normal menuntut perhatian khusus para pendidik. Fondamen kecakapan berbicara anak usia dini merupakan wujud fenomena yang menarik untuk dikaji hingga terjawab persalahan-permasalahan yang urgent sebagai wujud tanggungjawab orang tua, guru, dan pemerintah. Studi ini memperlihatkan kemampuan berbicara TK Islam YLPI Marpoyan selama masa new normal. Penelitian ini merupakan penelitian kualitatif guna menjelaskan persoalan-persoalan yang urgent terkait kompetensi berbicara pada anak usia dini pada masa new normal. Sumber data dokumen dan narasumber, dan teknik pengumpulan data melalui observasi, dokumentasi, dan wawancara. Analasis penelititian dilakukan secara induktif, dilakukan reduksi data hingga ferivikasi, dan pembahasan hingga ditemukan hasil penelitian yang bermakna. Hasil penelitian menunjukkan bahwa; (1) kompetensi berbicara anak usia dini masih dalam kategori rendah; (2) kurangnya komunikasi guru dan anak didik ketika pembelajaran online; (3) akibatnya anak diam ketika pembelajaran offline, kurang ceria, dan kurang optimis. Sehingga diperlukan usaha lebih dari pendidik untuk meningkatkan kompetensi berbicara anak usia dini dengan memperhatikan kebutuhan anak.
\end{abstract}

Kata Kunci: analisis; kompetensi berbicara; new normal

\begin{abstract}
The speaking competence of early childhood in the new normal requires special attention from educators. The foundation of speaking ability in early childhood is an interesting phenomenon to be studied until urgent problems are answered as a form of responsibility for parents, teachers, and the government. This study shows the speaking ability of YLPI Marpoyan Islamic Kindergarten during the new normal period. This research is a qualitative research to explain urgent issues related to speaking competence in early childhood in the new normal period. Sources of data are documents and sources, and data collection techniques are through observation, documentation, and in-depth interviews. Research analysis was carried out inductively, data reduction was carried out until verification, and discussion was carried out until meaningful research results were found. The results showed that; (1) speaking competence of early childhood is still in the low category; (2) the lack of communication between teachers and students when learning online; (3) as a result, children are silent when learning is offline, less cheerful, and less optimistic.
\end{abstract}

Keywords: analysis; speaking ability; new normal

Copyright (c) 2022 Siti Nur Hayati, Na'imah.

$\square$ Corresponding author :

Email Address : nurhaya912@gmail.com (Pekanbaru, Riau, Indonesia)

Received 17 November 2021, Accepted 23 January 2022, Published 22 February 2022 


\section{PENDAHULUAN}

Analisis kemampuan berbicara anak usia dini pada masa new normal menuntut perhatian dan tanggungjawab guru, orang tua, dan pemerintah. Persoalan kemampuan bersicara anak usia dini sungguh fundamental yang berpengaruh terhadap kehidupan masa depan, masyarakat, bangsa, dan negara. Hal ini sesuai dengan apa yang disampaikan Sumaryanti (2017) kemampuan berkomunikasi dengan bahasa merupakan hal mendasar dan sangat penting dalam perkembangan seorang anak. Melalui bahasa anak akan dapat mengembangkan kemampuan bergaul (social skill) dengan orang lain. Masa new normal merupakan dampak pandemi Covid-19. Pembelajaran jarak jauh (PJJ) telah dilaksanakan olhe lembaga TK Islam YLPI Marpoyan, yang merupakan suatu kejadian yang merupakan perwujudan isu yang penting dikaji dibelahan dunia pendidikan. Penelitian ini memperlihatkan 3 isu utama, yaitu (1) wujud apa yang telah terjadi dengan kompetensi berbicara anak usia dini di masa new normal; (2) alasan mengapa persoalan-persoalan tersebut terjadi; dan (3) wujud implikasi atas persoalan-persoalan yang terjadi dengan kompetensi anak usia dini di masa new normal. Kelemahan tersebut, tampak perbedaan jika dibandingkan masa pendidikan yang lain (Nahdi et al., 2020). Kompetensi berbicara anak usia dini sungguh penting dikaji, dikembangkan guna membangun generasi bangsa yang berkualitas dan mampu berkompetisi dalam percaturan ilmiah, secara nasional maupun internasional.

New normal merupakan masa pembelajaran tatap muka transisi kebiasaan baru yang dapat dilakukan oleh komponen pendidikan dan pengajaran (Shaleh \& Anhusadar, 2021). Masa transisi, seperti yang tertuang dalam buku saku yang disusun oleh Kementrian Agama, Kemendikbud, Kementrian Dalam Negeri, dan Kemenkes dengan judul Panduan Penyelenggaraan Pembelajaran di Masa Pandemi Covid-19. Lembaga yang termasuk dalam zona hijau dapat melaksanakan pembelajaran tatap muka dengan ketentuan mempriorotaskan jenjang ynag lebih tinggi karena pertimbangan bahwa siswa mampu mematuhi aturan terkait penerapan protokol kesehatan dengan melakukan physical distancing (jaga jarak). Ketentuan bahwa lembaga PAUD formal (TK, RA, TK Luar Biasa) dan non formal dapat melakukan pembelajaran tatap muka 2 bulan setelah lembaga pendidikan dengan tingkatan yang lebih tinggi seperti MI, SD, Paket A dan SLB (Kemdikbud, 2020).

Masa normal baru atau new normal, yaitu kegiatan yang dilakukan sehari-hari harus mengikuti gerakan $5 \mathrm{M}$, yakni : menggunakan masker, membasuh tangan dengan sabun dan air mengalir, menjauhi kerumunan, enjaga jarak, emmbatasi kegiatan di luar ruangan (Eniyati et al., 2021). Selain kesiapan lembaga dalam menghadapai masa new normal saat melakukan pembelajaran tatap muka, mematuhi protokol kesehatan sesuai dengan arahan dan ketetapan dari pemerintah daerah maupun pemerintah pusat juga harus diperhatikan (Ridwan et al., 2021). Persiapan masa new normal yang harus dilakukan lembaga adalah dengan selalu memakai masker bagi pendidik dan peserta didik, pengecekan suhu tubuh, durasi kegiatan pembelajaran, menjaga jarak tempat duduk di kelas, selalu mematuhi protokol kesehatan saat berkegiatan di luar kelas. Pemakaian masker bedah ataupun masker kain dalam setiap kegiatan, selalu terapkan pola hidup sehat dan bersih serta keterlibatan orang tua sangat dibutuhkan dalam menskrining siswa-siswi agar penularan virus Covid-19 dapat dicegah pada lingkungan sekolah.

Selain persiapan protokol kesehatan, berdasarkan surat edaran yang dikeluarkan oleh Pemerintah terkait pelaksanaan sekolah tatap muka terbatas di masa new normal (Sudrajat et al., 2020). Salah satunya yaitu pembatasan jam belajar dan pembatasan jumlah siswa yang masuk dalam satu hari. Dengan terbatasnya waktu yang dilakukan dalam kegiatan pembelajaran, tentu saja ini menjadi tanggung jawab besar bagi sekolah terutama sekolah anak usia dini dimana dengan waktu yang terbatas tersebut diharapkan guru dapat menyampaikan seluruh materi kegiatan dan pengembangan aspek perkembagan anak.

Aspek-aspek yang penting untuk diperhatikan pada tumbuh kembang anak adalah aspek sosial emosional, kognitif, bahasa, fisik motorik juga moral dan agama. Yang perlu 
mendapatkan perhatian khusus dalam penanganan salah satunya adalah aspek perkembangan bahasa. Dengan bahasa, anak dapat mengutarakan perasaan, berkomunikasi dengan lawan bicara, dapat memecahkan masalah dan masih banyak lagi. Aspek perkembangan bahasa anak sendiri dibagi menjadi kecakapan berbicara, menyimak, menulisa dan membaca. Salah satu dasar keterampilan bahasa anak usia dini yang harus dikembangkan dan diberi stimulasi adalah kemampuan berbicara.

Berbicara adalah suatu cara seseorang mengkomunikasikan serta mengutarakan perasaan dan keinginan yang dirasakan. Anak perlu memiliki keterampilan berbicara karena melalui berbicara anak dapat mengembangkan kemampuan bahasa, dan dapat melatih pemerolehan kosakata anak sehingga lebih kaya. Melalui kegiatan berbicara, dapat juga menjadi sebuah persiapan bagi anak untuk melanjutkan ke tahapan selanjutnya yaitu tahap menyimak, membaca dan juga menulis (Ruiyat et al., 2019).

Handoko menyatakan bahwa faktor-faktor yang berpengaruh terhadap kemampuan berbicara anak sehingga anak dapat mengalami gangguan berbicara. Faktor tersebut dapat dibagi menjadi faktor intern dan faktor ekstern (Isnainia \& Na'imah, 2020). Peran orang dewasa di sekitar anak sangat diperlukan dalam menstimulasi perkembangan anak. Tindakan diberikan sesuai dengan penyebab terjadinya gangguan (Matondang, 2019).

Sebagai alat komunikasi serta media untuk mengungkapkan perasaan, keterampilan berbicara termasuk dalam perkembangan bahasa paling urgent yang perlu distimulasi sejak dini.. Stimulasi perlu diberikan agar anak dapat mengatakan apa yang ada dalam pikirannya serta menggali segala sesuatu yang ingin anak ketahui. Berbicara adalah salah satu bentuk komunikasi lisan yang memiliki fungsi menyampaikan tujuan, memakai kata-kata dan kalimat secara jelas. Anak usia 3-5 tahun memiliki kosakata yang bervariasi, menjawab pertanyaan dengan komplek, perbendaharaan kata-kata semakin banyak, mengerti simbol huruf, berhitung, menulis serta menyusun kalimat sederhana dengan struktur lengkap, mempunyai banyak kata dalam menunjukkan ide terhadap orang lain serta mampu melanjutkan cerita yang didengar (Ruiyat et al., 2019).

Zuhriyah berpendapat bahwa peserta didik dapat dikatakan berhasil jika kemampuan berbicara anak semakin meningkat. Beberapa alasan anak mengalami kesulitan dalam berbicara antara lain anak memiliki sedikit ide sebagai bahan cerita, perbendaharaan kosakata yang sedikit, kesempatan berbicara yang kurang, serta metode pengajaran yang kurang menarik sehingga anak tidak bersemangat dalam berbicara (Matondang, 2019).

Tambunan Ruiyat et al. (2019) menyatakan bahwa setiap manusia normal memiliki kemampuan berbicara. Namun tidak berlaku untuk keterampilan berbicara, setiap manusia belum tentu memiliki keterampilan tersebut. Kemauan untuk belajar dan melatih kecakapan setiap hari membuat keterampilan berbicara seseorang menjadi semakin berkembang, sehingga ini dapat menepiskan anggapan jika tidak semua orang memiliki keterampilan berbicara. Hal tersebut tergantung dari seberapa besar seseorang ingin belajar dalam meningkatkan keterampilan yang diinginkan. Oleh karena itu sangat diperlukan pembelajaran berbicara pada lembaga pendidikan agar anak-anak dapat semakin terampil dalam berbicara.

Perkembangan bahasa anak terlihat masih kurang, hal ini diketahui dari observasi yang dilakukan kepada anak terlihat anak belum mampu mengungkapkan emosi melalui berbicara. Kesulitan ini dapat menjadi tanda bahwa anak perlu mendapatkan stimulasi agar dapat menyampaikan serta mengkomunikasikan pesan yang ingin disampaikan. Selain itu terdapat faktor lain yang dapat mengakibatkan lemahnya keterampilan berbicara anak anak yaitu kesempatan untuk berbicara. Dengan memberikan kesempatan anak untuk mengutarakan pendapat maka akan memberikan peluang bagi anak menyampaikan apa yang dirasa sehingga keterampilan berbicara anak dapat berkembang.

Pengulangan kata yang dilakukan secara intens akan melatih anak sehingga anak dapat mengetahui hal yang diinginkannya. Tujuan dari pengulangan itu sendiri adalah agar anak mampu mengutarakan apa yang sedang dirasakan. Pemerolehan kosakata pada anak 
sangat penting sebagai bekal bagi anak untuk tahap selanjutnya yaitu kemampuan menulis dan membaca. Keterampilan berbicara juga dapat memudahkan anak memahami bahasa selain itu anak semakin mudah mengontrol emosi dikarenakan keinginannya dapat diterima oleh lawan bicara dengan baik (Pratesi, 2018).

Berbicara dapat juga disebut sebagai kegiatan bercakap, berbahasa, berkata atau mengungkapkan pendapat. Melalui berbicara seseorang dapat mengutarakan gagasan, pendapat, ide serta perasaan kepada lawan bicara sehingga dapat memunculkan sebuah interaksi. Tarigan menyatakan bahwa berbicara merupakan kecakapan yang dimiliki seseorang dengan cara mengeluarkan bunyi artikulasi atau perkataan dengan tujuan menyatakan, mengekspresikan, mengutarakan gagasan, menyatakan perasaan yang dirasakan (Variansi et al., 2018).

Proses komunikasi yang memiliki tujuan untuk mengungkapkan gagasan, ide, pikiran serta maksud isi hati menggunakan bahasa lisan kepada lawan bicara. Anak dapat mengutarakan pikiran, pendapat dan perasaan melalui berbicara (Shofa \& Suparno, 2014). Orang yang memiliki kecakapan bicara cenderung lebih mudah menyampaikan gagasan, ide dan pendapat. Perlu pelatihan yang terus menerus agar seseorang terampil dalam berbicara, hal-hal yang perlu dilatih diantaranya : pengucapan, pelafalan, kontrol suara, diksi, kendali diri, kontrol gerak gerik tubuh, intonasi kalimat, pemakaian bahasa yang baik dan benar serta pengaturan ide (Pratesi, 2018).

Keterampilan berbicara sebagai rangsangan awal untuk meningkatkan perkembangan bahasa pada anak dikarenakan keterampilan berbicara pada anak adalah komunikasi efektif yang nantinya akan menjadi modal awal dalam kehidupan sosial anak. Aspek-aspek yang memiliki kaitan dengan perkembembangan kemampuan berbicara anak adalah tata bahasa, kosakata, semantic dan juga fonem. Semakin banyak kosakata yang dimiliki anak, semakin baik komunikasi anak dengan orang lain akan berpengaruh pula terahadap rasa percaya diri anak (Pradinda et al., 2020). Peran keterampilan berbicara pada kehidupan sosial anak adalah yang paling utama karena kegiatan berbicara akan selalu digunakan dalam kehidupan seharihari anak (Variansi et al., 2018).

Margareta (2020) menuliskan dalam artikel penelitian bahwa ketika peserta didik memiliki keterampilan komunikasi yang baik maka akan terjadi proses timbal balik dalam suatu pembelajaran. Selain itu dengan komunikasi yang baik antara pendidik dan peserta didik maka akan memudahkan pendidik dan peserta didik menjalin keakraban. Penggunaan metode pembelajaran yang tepat sangat diperlukan untuk meningkatkan keterampilan berbicara peserta didik.

Hasil penelitian lain menunjukkan, kemampuan berbicara anak usia 5-6 tahun di TK X Kamal menunjukkan bahwa anak sudah mampu mengucapkan 6-7 suku kata, anak mampu ikut serta dalam percakapan tanpa memonopoli, namun anak masih terkendala dalam penggunaan kata ganti waktu serta proses fonologis (Alfatihaturrohmah et al., 2018). Selain itu penelitian yang dilakukan oleh Variansi (Variansi et al., 2018) mengungkapkan anak usia 5-6 tahun di PAUD Tunas Unggulan yang kurang memiliki keterampilan berbicara dapat ditingkatkan dengan menggunakan metode sosiodrama. Dimulai dari proses pembelajaran, aktivitas belajar anak, serta bagaimana hasil keterampilan berbicara anak dengan menggunakan metode sosiodrama.

Ruiyat (2019) dalam penelitiannya mengungkapkan bahwa keterampilan berbicara anak semakin meningkat dan kebermaknaan pembelajaran pada anak akan mengakar dengan kuat jika pembelajaran yang disampaikan oleh guru ditunjang dengan penggunaan media yang tepat. Dengan kebermaknaan yang mengakar kuat, anak akan lebih mudah menceritakan kembali kegiatan yang telah dilakukan dengan akurasi jawaban yang sangat baik. Semakin berkembangnya tekhnologi serba digital memaksa guru harus menyesuaikan dan memperbaharui metode pembelajarannya. Komik digital dapat digunakan sebagai media untuk meningkatkan kosa kata anak melalui cerita yang disampaikan sehingga anak akan semakin terampil dalam berbicara. 
Tujuan dilakukannya penelitian ini adalah untuk memeroleh informasi yang berkaitan dengan keterampilan berbicara anak TK Islam YLPI Marpoyan di masa new normal. Analisis keterampilan berbicara pada masa new normal ini belum pernah diteliti sebelumnya. Hal-hal yang berkaitan dengan informasi yang ingin diperoleh antaran lain tentang keterampilan berbicara anak, perencanaan dan proses pembelajaran, evaluasi serta kendala dalam menerapkan pembelajaran keterampilan berbicara pada anak usia dini di TK Islam YLPI Marpoyan di masa new normal menjadi hal yang perlu diteliti. Perubahan pembelajaran online (dalam jaringan) yang biasanya anak selalu belajar dengan dampingan dan bimbingan orang tua yang notabene orang terdekat anak kemudian berganti menjadi pembelajaran tatap muka dengan dampingan dan bimbingan guru.

\section{METODOLOGI}

Penelitiaan ini menggunakan pendekatan kualitatif bersifat deskriptif analitik. Peneliti mengumpulkan data yang memiliki kaitan dengan konsep, situasi, pendirian, sikap dan penilaian suatu fenomena atau keadaan yang sebenarnya. Penelitian ini dilaksanakan di TK Islam YLPI di Jl Kaharuddin Nasution Km. 11 Perhentian Marpoyan, Kota Pekanbaru.

Penelitian ini memiliki batasan hanya pada orang yang memiliki peran dalam penelitian dan aktivitasnya, yakni analisis keterampilan berbicara anak usia dini dengan memperoleh informasi dari kepala sekolah, pendidik dan peserta didik di TK Islam YLPI Marpoyan, Kota Pekanbaru. Sumber data bersumber dari data primer dan sekunder. Yang masuk dalam sumber penelitian primer adalah kepala sekolah, pendidik dan peserta didik TK Islam YLPI Marpoyan Kota Pekanbaru. Sedangkan sumber data sekunder berasal dari dokumen pendukung yang di dapat dari sumber data primer. Banyaknya sumber data dipilih berdasar pertimbangan, sehingga peneliti berharap sumber yang ada dapat memberikan informasi sesuai dengan yang peneliti perlukan.

Teknik pengumpulan data menggunakan observasi, wawancara dan telaah dokumen. Wawancara dilakukan terhadap kepala sekolah danpendidik,. Pedoman wawancara telah melalui proses validasi oleh Dosen PIAUD UIR. Selain itu observasi juga dilakukan terhadap peserta didik dengan berpedoman kepada kisi-kisi observasi yang sudah disiapkan peneliti. Kemudian dilakukan juga telaah dokumen dengan cara pengumpulan data melalu dokumendokumen yang memiliki kaitan dengan keterampilan berbicara di TK Islam YLPI Marpoyan. Analisis data didapatkan dari hasil observasi, wawancara serta telaah dokumen yang memiliki kaitan dengan analisis keterampilan berbicara di TK Islam YLPI Marpoyan serta memberikan gambaran dan penjelasan terkait data yang didapatkan dalam bentuk kalimatadan terakhir melalukan penarikan kesimpulan. Tahapan penelitian dapat dilihat pada gambar 1.

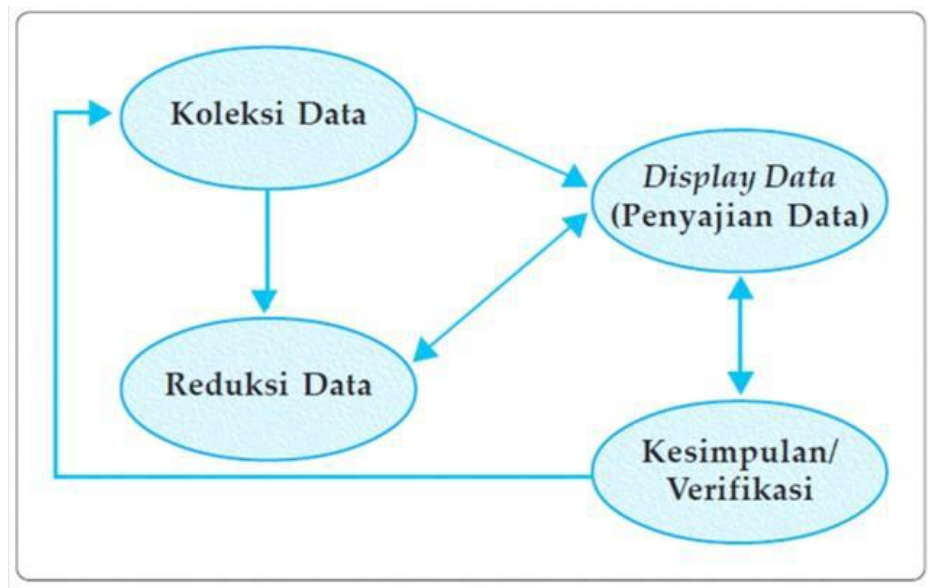

Gambar 1. Analisis data kualitatif Miles dan Huberman (Sugiyono, 2018) 


\section{HASIL DAN PEMBAHASAN \\ Perencanaan Pembelajaran Keterampilan Berbicara pada Anak Usia Dini di TK Islam YLPI Marpoyan}

Perubahan pembelajaran online menjadi offline menuntut lembaga PAUD memiliki kesiapan dalam menyusun pembelajaran sesuai ketetapan yang diberlakukan di masa new normal. Semakin menurunnya kasus Covid-19 di daerah Pekanbaru membuat TK Islam YLPI Marpoyan Pekanbaru mendapatkan izin untuk melaksanakan pembelajaran tatap muka langsung. TK Islam YLPI Marpoyan merupakan lembaga pendidikan swasta di bawah naungan Yayasan Lembaga Pendidikan Islam. TK YLPI memiliki 1 kepala sekolah dan 4 tenaga pendidik, selain itu lembaga tersebut memiliki 4 kelompok bermain yang masingmasing kelompoknya terdiri dari 14 anak.

Seluruh komponen yang ada di TK Islam YLPI Marpoyan dalam hal ini pengelola dan pendidik sangat memahami bhwa berhasil tidaknya implementasi pembelajaran kecakapan berbicara anak di TK Islam YLPI Marpoyan sangat membutuhkan sebuah rencana yang terarah dan tersusun demi tercapainya tujuan proses pembelajaran. Sesuai dengan observasi yang dilakukan terlihat guru telah melakukan kegiatan pembelajaran sesuai dengan scenario yang ada. Scenario pembelajaran merupakan urutan langkah-langkah yang dibuat oleh guru dengan tujuan agar pembelajaran yang ingin disampaikan dapat berjalan sesuai rencana (Suningsih, 2018).

Selain itu bentuk lain dari perencanaan pembelajaran dapat juga berupa sebuah kurikulum. Pendapat Wood Kurikulum adalah salah satu bentuk perencanaan yang dilakukan sebuah lembaga agar tercapainya tujuan pendidikan. Hal ini didukung dengan pernyataan Kepala Sekolah TK Islam YLPI yang secara terang menyatakan bahwa "tanpa adanya sebuah kurikulum tentu saja rencana pembelajaran tidak dapat disusun oleh tim dan dijadikan pedoman dalam kegiatan pembelajaran. TK Islam YLPI Marpoyan menggunakan Kurikulum 2013 sebagai acuan dalam menyusun rencana pembelajaran. Tapi karena TK Islam YLPI Marpoyan ini berada di bawah naungan Yayasan dan memiliki kurikulum sendiri maka pihak TK mengkolaborasikan antara Kurikulum 2013 dengan kurikulum Yayasan yang berbasis Islam "(A, 1 November 2021).

Senada dengan yang disampaikan oleh guru kelas B1 bahwa "TK Islam YLPI ini menggunakan Kurikulum 2013, sebelum guru melakukan kegiatan pembelajaran tentu saja guru menyusun scenario agar nanti kegiatan pembelajaran dapat berjalan sesuai rencana, apa yang ingin dicapai hari ini dapat dilaksanakan, dan agar tidak ada yang terlewat karna tanpa scenario bisa saja ada hal-hal yang dilewatkan" (AA, 27 Oktober 2021).

Hal yang sama juga disampaikan oleh guru kelas B3 dimana "kami tim guru sebelum melaksanakan kegiatan pembelajaran apalagi new normal ini kan jamnya dibatasi jadi perencanaan yang awalnya bisa sampai tengah hari baru selesai ini jam 11 anak-anak harus sudah pulang semua. Perencanaan biasanya dilakukan bersama guru yang lain juga, rpph kami diskusikan untuk pembelajaran hari selanjutnya apa saja yang perlu disiapkan. Pembelajaran itu semua mencakup seluruh aspek perkembangan anak" (TM, 29 Oktober 2021)

Berdasar pernyataan-pernyataan dari hasil wawancara dan telaah dokumen yang diperoleh peneliti terhadap kepala lembaga, dan pendidik di TK Islam YLPI Marpoyan diketahui bahwa yang termasuk dalam perencanaan pembelajaran keterampilan berbicara di TK Islam YLPI Marpoyan dituangkan dalam bentuk Kurikulum PAUD 2013 dan karena lembaga merupakan sekolah Islam maka lembaga memiliki kurikulum tambahan yang dikombinasikan dengan Kurikulum PAUD 2013. Kurikulum tersebut merupakan buah pemikiran dari penyelenggara, kepala sekolah, dan pendidikan TK Islam YLPI Marpoyan sebelum tahun ajaran baru dimulai. Guru menyiapkan seknario pembelajaran, langkahlangkah dalam proses pembelajaran, serta guru menulis rencana penilaian dalam setiap kegiatan yang dilakukan peserta didik.

Tim pengembang kurikulum di TK Islam YLPI Marpoyan menyiapkan kurikulum dengan penuh perencanaan dan dipikirkan secara matang-matang dengan mengutamakan prinsip pengembangan kurikulum bagi anak usia dini. Prinsip tersebut dijalankan supaya 
pesertaddidik memperoleh stimulasi atau rangsangan serta mendapatkan pengalaman belajar yang menarik, memiliki makna, bermutu sesuai dengan bakat, minat dan potensi anak usia dini. Pengembangan kurikulum di TK Islam YLPI Marpoyan disusun oleh tim pengembang kurikulum dengan memperhatikan ketetapan prosedur yang ada, diawali dari telaah konteks, pengorganisasian setelah itu pengabsahan. Telaah konteks dilaksanakan dengan memahami dan menelaah aturan-aturan dan undang-undang yang memiliki kesesuaian dengan aturan dasar pengembangan kurikulum. Telaah kontek dilaksanakan untuk memanifestasikan visi, misi, tujuan dan srategi yang nantinya dilaksanakan.

Tabel 1. Rencana Pelaksanaan Pembelajaran Harian

\begin{tabular}{|c|c|}
\hline $\begin{array}{c}\text { Proses } \\
\text { Kegiatan }\end{array}$ & Aktivitas \\
\hline Mulok & $\begin{array}{l}\text { - } \quad \text { Shalat Dhuha } \\
\text { - } \quad \text { Iqra' }\end{array}$ \\
\hline Toilet Training & $\begin{array}{l}\text { - } \quad \text { Mengikuti aturan sederhana } \\
\text { - } \quad \text { Pembiasaan hidup bersih dan sehat }\end{array}$ \\
\hline Pembukaan & $\begin{array}{l}\text { - Pembiasaan mengamati, bertanya, mengkomunikasikan dan menalar } \\
\text { - } \quad \text { Mentuk mencari tahu } \\
\text { - } \quad \text { Pembiasaan mengikuti aturan sederhana } \\
\text { - } \quad \text { Pengenalan dan pembiasaan berbagai doa sebelum melakukan kegiatan } \\
\text { - } \quad \text { Mengajak anak berkomunikasi, mengemukakan pendapat, pengalaman } \\
\text { sehari-hari } \\
\text { - Memberikan kesempatan pada anak untuk memilih kegiatan bermain } \\
\text { yang disukainya }\end{array}$ \\
\hline Inti & $\begin{array}{l}\text { - Pembiasaan membuat sesuatu dengan ide sendiri } \\
\text { - } \quad \text { Pembiasaan berani melakukan tantangan baru } \\
\text { - } \quad \text { Pembiasaan melakukan kegiatan secara mandiri } \\
\text { - } \quad \text { Bermain aktif dengan berbagai alat dan bahan untuk mengenalkan } \\
\text { budaya, lingkungan alam dan fenomenanya, keaksaraan awal, } \\
\text { penggunaan alat secara cepat dan menghasilkan hasil karya seni } \\
\text { Pembiasaan berkata sopan (mengucapkan kata terima kasih, maaf dan } \\
\text { tolong) }\end{array}$ \\
\hline Recalling & $\begin{array}{l}\text { - Pembiasaan menghargai hasil karya diri dan teman } \\
\text { - } \quad \text { Mengajak anak berkomunikasi, mengemukakan pendapat dan } \\
\text { pengalaman sehari-hari } \\
\text { - } \quad \text { Merapikan alat-alat yang telah digunakan } \\
\text { - } \quad \text { Diskusi tentang perasaan diri selama melakukan kegiatan bermain } \\
\text { - Bila ada perilaku yang kurang tepat harus didiskusikan bersama }\end{array}$ \\
\hline Istirahat/makan & $\begin{array}{l}\text { - Pembiasaan perilaku hidup bersih dan sehat } \\
\text { - } \quad \text { Pembiasaan bersyukur pada Tuhan }\end{array}$ \\
\hline Penutup & $\begin{array}{ll}\text { - } & \text { Menanyakan perasaannya selama hari ini } \\
\text { - } & \text { Menginformasikan kegiatan untuk besok } \\
\text { - } & \text { Berdoa pulang }\end{array}$ \\
\hline Rencana & - Penilaian sikap \\
\hline Penilaian & - Penilaian pengetahuan dan keterampilan \\
\hline
\end{tabular}

Sumber : TK Islam YLPI Marpoyan

Berdasar hasil telaah dokumen serta wawancara terhadap kepala lembaga, dan pendidik didapatkan informasi bahwa keseluruhan kurikulum yang dijadikan acuan berisi filososi, visi, misi, tujuan, ciri atau karakteristik kurikulum, program khusus dan umum, struktur pembelajaran, prosem, rppm, rpph, alokasi waktu, kalender pendidikan serta evaluasi. Pelaksanaan perencanaan pembelajaran sangat penting dilaksanakan supaya aktivitas yang akan dilakukan memiliki arah dan tujuan sehingga pembelajaran yang 
disampaikan dapat mengembangkan aspek perkembangan anak dan dapat berjalan sesuai rencana. Penyusunan perencanaan pembelajaran dilaksanakan oleh pendidik dengan memperhatikan karakteristik anak. Penyusunan dilakukan dengan berlandaskan pada STTPA (Standar Tingkat Pencapaian Perkembangan Anak). Prosem (program semester) yang dirancang selanjutnya dikembangkan menjadi RPPM (Rencana Pelaksanaan Pembelajaran Mingguan) yang akan dilaksanakan selama seminggu. RPPM di TK Islam YLPI Marpoyan memuat identitas program, materi pembelajaran, KD yang dipilih, serta rencana kegiatan dalam kurun waktu seminggu yang tentunya kegiatannya akan berbeda setiap harinya. RPPM tersebut nantinya akan dijabarkan lagi dalam RPPH (Rencana Pelaksanaan Pembelajaran Harian). Pelaksanaan RPPH dilakukan oleh pendidik sebagai bahan acuan dalam melakukan kegiatan pembelajaran dalam satu hari. Di dalam RPPH berisikan kelompok usia, minggu/bulan/semester, tema/sub tema, KD yang ditetapkan, materi pokok, materi SOP pembiasaan, alat dan bahan, kegiatan pembuka, inti, penutup serta rencana penilaian.

Sejak adanya pandemic covid-19, TK Islam YLPI mengadakan perubahan terhadap Prosem (program Semester) sampai RPPM dan RPPH dan ini dilakukan untuk menyesuaikan kondisi yang ada. Dikeranakan kegiatan tatap muka hanya diperbolehkan paling lama adalah 3 jam dan pembelajaran hanya 3 kali dalam sepekan.

\section{Proses Pembelajaran pada Anak Usia Dini di TK Islam YLPI Marpoyan}

Hasil wanacara, telaah dokumen dan observasi yang dilakukan terhadap kepala lembaga dan tenaga pendidik di TK Islam YLPI Marpoyan dapat disimpulkan bahwa TK Islam YLPI Marpoyan menggunakan pembelajaran dengan pendekatan saintifik dimana pendekatan ini pelaksanaannya berdasar aturan yang tertuang dalam Kurikulum PAUD 2013. Harapannya dengan pendekatan saintifik ini anak mengembangkan keterampilan, sikap dan pengetahuan serta memperoleh pengalaman belajar secara langsung. Pendekatan saintifik dapat dilihat saat anak melaksanakan kegiatan inti, dimana pada kegiatan tersebut anak menngamati, mengajukan pertanyaan, menyerap informasi, menalar dan mengkomunikasikan.

Metode pembelajaran keterampilan berbicara sebagai upaya untuk meningkatkan kemampuan bahasa anak. Sukses atau gagalnya suatu pembelajaran dapat diketahui dari tercapai atau tidaknya tujuan pembelajaran, dan dapat dikatakan sukses jika terjadi perubahan yang positif pada hasil belajar anak. Sehingga terkait dengan penggunaan metode, pendekatan dan strategi yang berpengaruh besar terhadap pencapaian hasil belajar siswa (Purwanita et al., 2019). Teknik pembelajaran yang dapat digunakan pada pendidikan anak usiad ini diantaranya tanya jawab, bercerita, pembiasaan, demonstrasi, karyawisata dan pemberian tugas.

Kesimpulan dari pemaparan di atas adalah kegiatan pembelajaran di TK Islam YLPI Marpoyan tidak terlepas dari upaya untuk meningkatkan kemampuan bahasa pada peserta didik. Kemampuan bahasa anak terutama keterampilan berbicara distimulasi dengan bermacam-macam metode pada setiap kegiatan pembelajaran. Metode yang digunakan adalah metode bercakap-cakap dan tanya jawab yaitu cara pendidik meningkatkan keterampilan berbicara anak dengan mengajak anak bercakap-cakap. Dengan metode ini anak akan mengutarakan apa saja yang ingin dia sampaikan melalui ucapan. Anak menceritakan kegiatan sebelum berangkat sekolah, kemudian apa menu sarapan paginya, siapa yang mengantar sekolah hari ini dan lain sebagainya. Tentu metode ini tak luput dari peran guru yang selalu menstimulasi anak agar anak dapat mengutarakan dan menceritakan apa saja yang anak kerjakan atau alami sebelum berangkat sekolah. Selain itu ada metode bercerita, pada metode ini biasanya guru akan menyampaikan terlebih dahulu narasi berkaitan dengan tema pembelajaran hari ini. Selanjutnya guru meminta anak menuturkan kembali apa saja yang telah guru sampaikan. Selain dengan menceritakan kembali cerita yang dibacakan oleh guru, anak juga dapat menunjukkan hasil karya anak di depan kelas dan menjelaskan apa 
yang hari ini anak kerjakan. Kemudian diakhir pembelajaran, guru akan melakukan recalling tentang apa saja kegiatan yang dilakukan anak hari ini. Dengan recalling diharapkan, daya ingat anak akan berkembang dan dapat mengungkapkan apa yang diingatnya melalui bahasa lisan. Kondisi kegiatan bercerita dengan menggunakan buku cerita bergambar dapat dilihat pada gambar 2.

Hasil wawancara dengan salah satu anak didik dengan inisial A kelompok B3 "Abang tadi bermain cerita, ada semut sama kepompong. Semut jatuh di lumpur, semutnya ditolong kupukupu. Kata Bu TM (guru kelompok B3) sama teman harus tolong menolong seperti semut dan kupukupu" (A, 29 Oktober 2021). Senada dengan A, peserta didik dengan inisial Y juga menyatakan hal yang sama "tadi bercerita dengan Bu TM senang. Ada semut jatuh di lumpur. Kata Bu TM besok main cerita lagi" (Y, 29 Oktober 2021). Berbeda halnya dengan A dan Y, peserta didik berinisial $\mathrm{K}$ justru tidak merespon apa yang peneliti tanyakan, sesekali anak hanya menjawab " $n d a k$ " kemudian pergi.

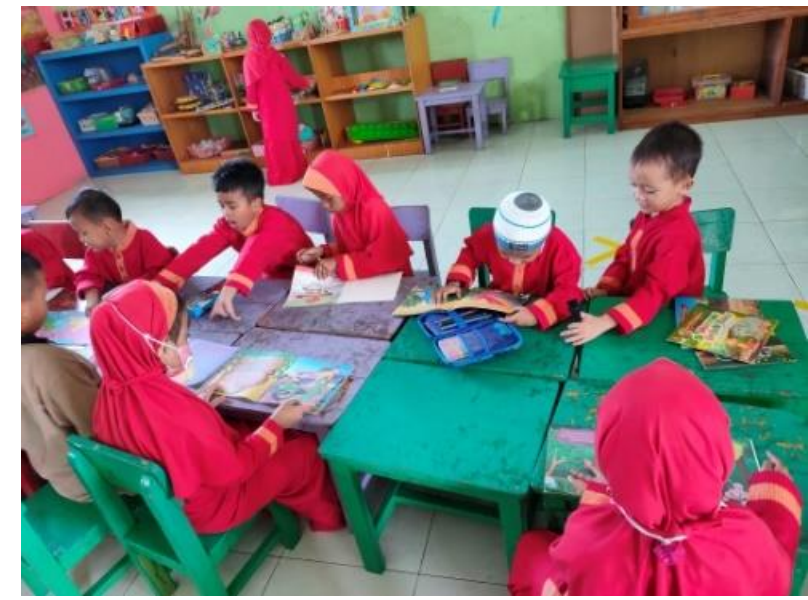

Gambar 2. Kegiatan bercerita dengan buku cerita bergambar

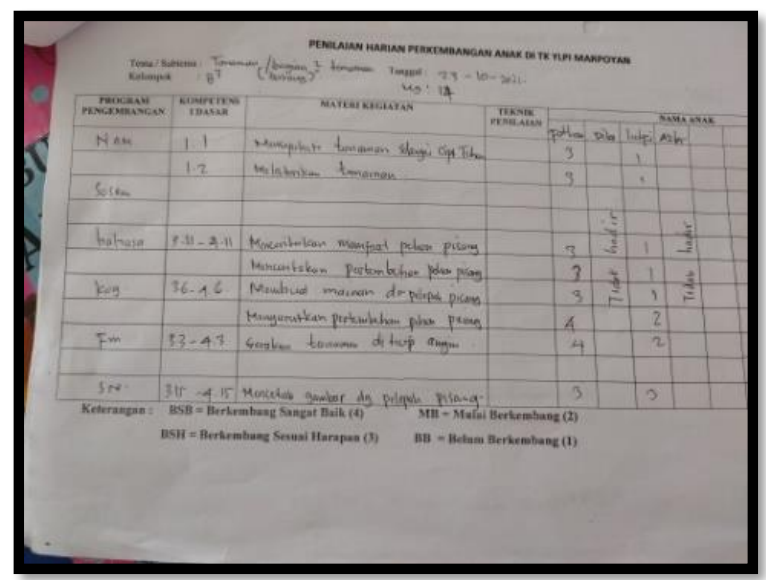

Gambar 4. Penilaian harian TK Islam YLPI Marpoyan

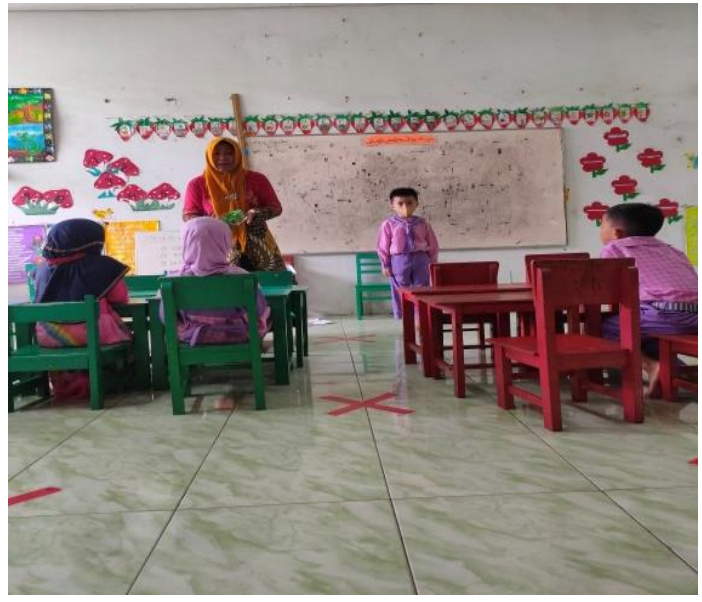

Gambar 3. Kegiatan pembelajaran yang hanya dihadiri beberapa anak

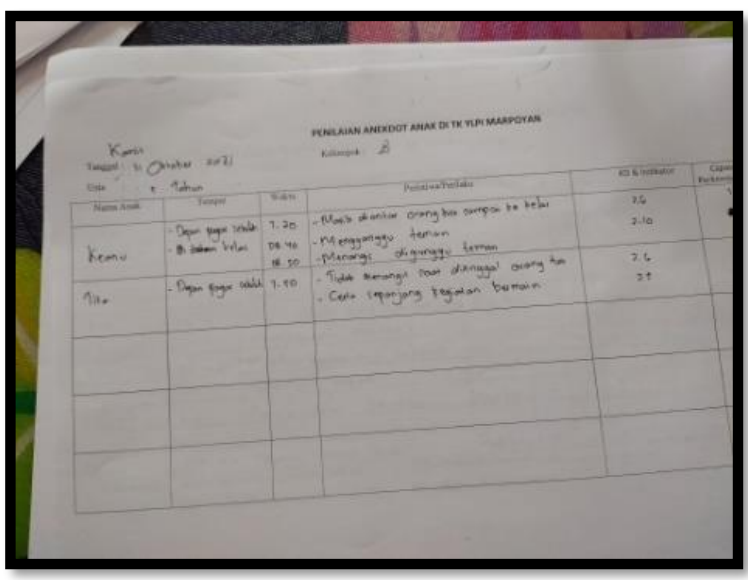

\section{Evaluasi Kemampuan Berbicara Pada Anak Usia Dini di TK Islam YLPI Marpoyan}

Berhasil tidaknya suatu program dapat dilakukan dengan cara melakukan evaluasi. Evaluasi yang baik adalah salah satunya yang dapat memberikan data dan informasi yang bermanfaat untuk perbaikan suatu program, sebagai bentuk tindak lanjut hasil evaluasi (Ningrum, 2019). Ketercapaian kemampuan bahasa pada anak usia dini di TK Islam YLPI Marpoyan dilaksanakan melalui penilaian. Penilaian dilakukan untuk melihat capaian perkembangan anak. Dampak dan progress tumbuh kembang anak dapat dilihat dari capaian 
hasil belajar dimana hasil yang didapat merupakan bagian dari proses penilaian (Kemendikbud, 2021).

Hasil wanacara dengan guru kelompok B2 menyatakan bahwa "penilaian dilakukan setiap hari, karena pembatasan jumlah peserta didik yang masuk maka guru melakukan penilaian hanya beberapa anak saja tiap harinya jadi tidak bisa semuanya langsung. Penilaiannya ada ceklis dan catatan anekdot, yang dinilai tentu semua aspek perkembangannya" ( UH, 28 Oktober 2021). Hal serupa juga diungkapkan oleh guru kelompok B1 yang menyatakan "evaluasi dilakukan setiap hari, tapi dibagi-bagi hari ini berapa anak yang dinilai besok siapa lagi seperti itu. Kalau yang sudah dinilai hari ini besok tidak dinilai lagi tapi tetap terus dipantau perkembangannya dan bisa jadi ada yang dimasukkan ke dalam catatan anekdot tentang perilaku yang tidak biasa anak lakukan" (AA, 27 Oktober 2021). Hal ini diperkuat oleh pernyataan Kepala Sekolah yang menyatakan bahwa “ evaluasi selalu dilakukan oleh guru kelas bahkan evaluasinya dilakukan setiap hari, hal ini bertujuan untuk mengetahui perkembangan anak. Baru nanti hasilnya diserahkan ke orang tua peserta didik setiap penerimaan rapor" (A, 1 November 2021).Berdasarkan wawancara, observasi dan telaah dokumen yang dilakukan TK Islam YLPI Marpoyan dapat disimpulkan bahwa TK Islam YLPI Marpoyan dilaksanakan secara teratur setiap harinya dengan berpatokan dengan prinsip penilaian yang bersifat objektif. Maksud dari kegiatan evaluasi adalah untuk mendapatkan informasi terkait perubahan sikap anak didik setelah mengikuti kegiatan pembelajaran.

Penilaian yang dilakukan di TK Islam YLPI Marpoyan dilaksanaan setiap semester, setiap bulan dan setiap hari. Guru melakukan penilaian harian dengan mengamati kegiatan anak selama atau seusai kegiatan. Berdasar pada ketentuan Kurikulum 2013 PAUD, bahwa penilaian tumbuh kembang harus dilakukan sesuai fakta sesungguhnya (Murti, 2020). Prinsip penilaian ini biasa disebut dengan penilaian otentik, prinsip ini memiliki tujuan yakni mengukur tingkat kemampuan kompetensi pengetahun, sikap serta keterampilan anak. Format yang dipakai dalam penilaian harian dapat berupa hasil karya, ceklis serta catatan anekdot. Kumpulan penilaian harian yang dilakukan dalam kurun waktu satu bulan nantinya akan direkap oleh guru menjadi penilaian bulanan, setelah satu semester direkap kembali menjadi penilaian semester sehingga hal tersebut menjadi dasar untuk pelaporan kepada orang tua pada penerimaan rapor anak setiap semesternya.

Penilaian-penilaian yang dilakukan guru baik itu penilaian harian, kemudian dari penilaian harian tersebut selanjutnya direkapitulasi menjadi penilaian mingguan dan dalam jangka waktu enam bulan menjadi penilaian semester. Hasil dari penilaian tersebut akan menjadi pedoman saat pelaporan tumbuh kembang anak kepada orang tua. Hal ini bertujuan untuk menyampaikan hasil peningkatan capaian perkembangan anak baik dari sikap, keterampilan dan pengetahuan serta tumbuh kembang anak secara fisik. Dalam jangka waktu 2 kali dalam satu tahun, TK Islam YLPI Marpoyan melakukan pelaporan rutin perkembangan anak kepada orang tua. Sedangkan untuk pelaporan yang bersifat incidental dilakukan saat terjadi hal-hal tertentu pada anak saat di sekolah dan memerlukan penanganan segera. Untuk penilaian harian pada masa new normal ini, dikarenakan anak hanya melakukan pembelajaran 3 kali dalam sepekan dana jumlah anak yang dibatasi dalam pembelajaran maksimal 50\% dari jumlah keseluruhan maka guru dapat sekaligus menilai perkembangan anak dalam satu hari. Jika dibandingkan sebelum pandemi, TK Islam YLPI melakukan penilaian harian dengan memfokuskan beberapa anak saja dalam sehari dengan catatan tetap memperhatikan perkembangan anak-anak yang lain juga. Contoh pengisian penilaian harian dapat dilihat pada gambar 4 .

Selain melakukan evaluasi terhadap kemampuan anak, lembaga juga melakukan evaluasi proses pembelajaran di akhir tahun. Hal ini bertujuan untuk mengetahui kendala yang dihadapai guru dalam pengimplementasi kurikulum, mengetahui capaian indikator yang digunakan, sehingga menjadi bahan dalam perbaikan indikator kurikulum ke dapannya. Sehingga pada TK Islam YLPI ini bukan hanya anak saja yang perlu dilakukan evaluasi tentang indikator kemampuan apa yang sudah anak capai dan belum dicapai, tetapi juga 
evaluasi terhadap proses pembelajaran agar nantinya menjadi bahan untuk perbaikan sehingga dapat memberikan penanganan yang tepat serta perubahan ke arah yang lebih baik. Diharapakan dengan evaluasi nantinya lembaga dapat melakukan pelayanan yang masimal dalam menumbukembangkan seluruh aspek perkembangan anak diantarnya yaitu kemampuan berbicara.

Evaluasi juga dilakukan oleh peneliti dimana peneliti ingin mengatahui keterampilan berbicara anak usia dini di TK Islam YLPI Marpoyan. Peneliti menggunakan indikator keterampilan berbicara dari Allen dan Marotz (Alfatihaturrohmah et al., 2018) sebagai acuan untuk melakukan observasi terhadap keterampilan berbicara anak kelompok B di TK Islam YLPI Marpoyan. Dari indikator pada tabel 2, peneliti mendapati bahwa keterampilan berbicara anak usia dini di TK Islam YLPI Marpoyan di masa new normal dapat dikatakan masih rendah. Selain itu dilihat dari sedikit anak yang mampu dengan jelas mengungkapkan apa yang ingin disampaikan dan masih sedikit anak yang mampu menjawab pertanyaan dari guru terkait pembelajaran. Akibatnya anak menjadi murung saat di sekolah, kurang bersemangat, dan kurang optimis saat mengikuti pembelajaran. Hal ini terjadi karna peralihan pembelajaran yang semula online menjadi offline. Saat pembelajaran online, anak-anak jarang berkomunikasi dengan guru kelas. Tugas-tugas diberikan secara online atau orang tua datang ke sekolah untuk menjemput tugas. Oleh karena itu perlu pelatihan agar softskill anak menjadi berkembang. Kegiatan pembelajaran offline atau luring menjadi waktu yang tepat bagi pendidik untuk mengembangkan keterampilan berbicara anak yaitu dengan banyak melakukan komunikasi dua arah.

Tabel 2. Indikator keterampilan berbicara anak usia 5-6 tahun

\begin{tabular}{|c|c|c|c|c|c|}
\hline $\begin{array}{c}\text { Usia } \\
\text { Anak }\end{array}$ & Kemampuan Berbicara & BSB & BSH & MB & BB \\
\hline $\begin{array}{c}\text { 5-6 } \\
\text { Tahun }\end{array}$ & $\begin{array}{l}\text { 1. Menceritakan cerita yang sudah dia kenal ketika melihat } \\
\text { gambar pada buku. } \\
\text { 2. Menyebutkan kegunaan sesuatu: sendok untuk makan, } \\
\text { gelas untuk minum. } \\
\text { 3. Menyebutkan empat sampai delapan warna. } \\
\text { 4. Mengucapkan kalimat dengan lima sampai tujuh kata atau } \\
\text { lebih panjang. } \\
\text { 5. Menyebutkan data pribadi, nama anak, tempat tinggal. } \\
\text { 6. Menjawab telepon, memanggil orang yang ditelepon. } \\
\text { 7. Mengucapkan kalimat-kalimat yang dapat dipahami } \\
\text { orang lain. } \\
\text { 9. Menggunakan kata "bolehkah saya" dengan tepat, } \\
\text { 10. Bercakap-cakap seperti orang dewasa, banyak bertanya. } \\
\text { 11. Menggunakan bentuk kata kerja, urutan kata dan struktur } \\
\text { kalimat yang tepat. } \\
\text { 12. Berbicara sendiri sambil menentukan langkah-langkah } \\
\text { 13. Mang diperlukan untuk memecahkan masalah. }\end{array}$ & & & & \\
\hline
\end{tabular}

\section{Kendala dalam Pembelajaran Kemampuan Berbicara pada Anak Usia Dini di TK Islam YLPI Marpoyan}

Keberhasilan pendidikan kemampuan bahasa di TK Islam YLPI Marpoyan dapat dicapai jika ada kerjasama baik dari berbagai pihak. Melalui lingkungan sekolah, keluarga dan masyarakat, anak-anak belajar untuk menyelidiki dunia dan mengetahui untuk belajar dalam hal sikap dan perilaku melalui konteks keluarga. Memiliki lingkungan belajar yang positif dapat menumbuhkan keterampilan dan mendorong pembelajaran aktif untuk anak usia dini (Kumalasari \& Sugito, 2020). Pendidikan kemampuan bahasa anak akan semakin berkembang 
tatkala orang tua, pendidik serta masyarakat mampu memberikan sumbangan yang positif. Implementasi pendidikan kecakapan bahasa pada anak di TK Islam YLPI Marpoyan tidak selalu berjalan dengan mudah sesuai yang direncanakan. Banyak faktor penghambat dan pendukung keberhasilan pengimplementasian pendidikan kemampuan bahasa yang terjadi di lembaga tersebut. Setelah pengumpulan data hasil wawancara terlihatlah faktor yang menjadi kendala dalam kompetensi berbicara anak adalah orang tua, lembaga itu sendiri serta lingkungan tempat anak berada.

Kendala yang menghambat kemampuan bahasa pada anak yang berasal dari orang tua terjadi karena kurangnya pemahaman orang tua tentang seperti apa kemampuan bahasa anak, bagaimana memberikan stimulasi yang tepat pada setiap tahapan usia serta hal apa yang harus dilakukan jika anak memiliki kendala dalam kemampuan bahasa seperti yang disajikan pada tabel 3. Selain itu kurangnya dukungan orang tua terhadap program sekolah dan tidak adanya pendidikan yang berkelanjutan dari orang tua saat berada di lingkungan keluarga. Pengaruh pembelajaran online membuat anak selalu bergantung dengan orang tua sehingga anak kurang berkomunikasi langsung dengan guru. Akhirnya hubungan antara guru dan peserta didik tidak terjalin dengan erat.

Tabel 3. Kendala keterampilan berbicara anak usia dini

\begin{tabular}{ccl}
\hline Kendala & & \multicolumn{1}{c}{ Uraian } \\
\hline \multirow{2}{*}{ Orang tua } & - & Kurang memberikan dukungan \\
& - & Anak bergantung dengan orang tua \\
& - & Fasilitas yang kurang \\
Lembaga & - & Guru kurang kreatif \\
& - & Guru kurang responsive \\
& - & Terbatasnya waktu pembelajaran \\
Lingkungan & - & Terbatasnya jumlah murid yang hadir \\
\hline
\end{tabular}

Kendala yang berasal dari lembaga diantaranya kurangnya fasilitas yang disediakan, terbatasnya sarana dan prasarana, kurangnya kreativitas guru dalam memanfaatkan media lain dalam mengembangkan kemampuan bahasa anak selain itu guru juga kurang responsive ketika anak mulai mengajak berkomunikasi dikarenakan ada beebrapa anak yang tidak mahu sama sekali melepas maskernya ketika berbicara sehingga guru kurang mendengar apa yang disampaikan oleh anak.

Terbatasnya waktu untuk kegiatan pembelajaran juga menjadi kendala yang dihadapi oleh lembaga. Sepanjang kegiatan tatap muka era new normal ini, lembaga hanya diperbolehkan melakukan kegiatan pembelajaran selama 3 jam saja dalam satu hari. Selama 3 jam inilah semua kegiatan untuk mengembangkan seluruh aspek perkembangan pada anak di padatkan, sehingga guru dan anak-anak harus benar-benar memanfaatkan waktu yang ada dengan semaksimal mungkin. Biasanya guru dapat lebih lama untuk bercerita atau berbincang dengan anak, dalam masa ini kegiatan tersebut sedikit dikurangi karena dalam kegiatan sehari tersebut anak harus menyelesaikan kegiatan yang lain. Kondisi pembelajaran diilustrasikan dengan gambar 3.

Pembatasan jumlah murid dalam satu kelas yang hanya diperbolehkan sekitar $50 \%$ dari jumlah keseluruhan, membuat lembaga mencari solusi agar kegiatan yang telah dirancang dapat tersampaikan dan mengembangkan seluruh aspek perkembangan anak yaitu dengan melakukan giliran belajar, untuk rombongan Senin 7 anak, Selasa \& anak yang berbeda lagi, dan begitu seterusnya sampai hari Jumat. Khusus pada penelitian ini peneliti fokus terhadap kelas B yang terbagi dalam 3 kelompok yaitu B1, B2 dan B3 terdapat sekitar 14 anak pada setiap kelompoknya. 
Kendala yang menghambat keterampilan berbicara anak dari lingkungan terjadi karena masih diberlakukannya pembatasan sosial sehingga anak tidak dapat melaksanakan kegiatan bermain di lingkungan. Kegiatan anak hanya dapat dilakukan di dalam lingkungan rumah saja. Oleh karena itu pemerolehan bahasa yang di dapat anak juga kurang terasah karena kurangnya berkomunikasi dan bersosialisasi dengan lingkungan sekitar.

\section{SIMPULAN}

Kompetensi berbicara anak usia dini di TK Islam YLPI Marpoyan di masa new normal ini masuk dalam kategori rendah. Dapat dilihat dari sedikit anak yang mampu dengan jelas mengungkapkan apa yang ingin disampaikan dan masih sedikit anak yang mampu menjawab pertanyaan dari guru terkait pembelajaran. Akibatnya anak menjadi murung saat di sekolah, kurang bersemangat, dan kurang optimis saat mengikuti pembelajaran. Perencanaan pembelajaran, proses pembelajaran serta evaluasi yang dilakukan TK Islam YLPI Marpoyan tidak jauh berbeda dengan perencaaan, proses, dan evaluasi pembelajaran sebelum diberlakukan pembelajaran masa new normal. Pneeliti melihat bahwa pengaruh pembelajaran online yang biasa anak selalu dibantu dan dibimbing oleh orang tua membuat anak mengalami ketergantungan ingin selalu dibantu orang tua saat menyelesaikan tugas, sehingga ketika anak bertemu langsung dengan guru akan membuat anak sedikit kurang nyaman dalam pembelajaran. Selain itu pembatasan waktu belajar membuat durasi anak bertemu dengan guru dan teman-teman menjadi singkat, dan pembatasan jumlah murid membuat anak merasa kurang semangat ketika teman yang dekat dengan anak tidak masuk dalam giliran yang sama. Sehingga diperlukan usaha lebih dari pendidik untuk meningkatkan kompetensi berbicara anak usia dini dengan memperhatikan kebutuhan anak.

\section{UCAPAN TERIMA KASIH}

Terimakasih kepada sekolah TK Islam YLPI Marpoyan atas kesempatan yang diberikan kepada peneliti sehingga dapat melaksanakan penelitian, membagikan informasi terkait pengimplementasian pembelajaran masa new normal dan analisis kompetensi berbicara pada anak selama era new normal.

\section{DAFTAR PUSTAKA}

Alfatihaturrohmah, A., Mayangsari, D., \& Karim, M. B. (2018). Kemampuan Berbicara Anak Usia 5-6 Tahun di TK X Kamal. Jurnal PG-PAUD Trunojoyo : Jurnal Pendidikan Dan Pembelajaran Anak Usia Dini, 5(2), 101-109. https://doi.org/10.21107/pgpaudtrunojoyo.v5i2.4885.

Eniyati, S., Lusiana, V., Hartono, B., Husni, I., Amin, A., Studi, P., Informatika, T., Informasi, F. T., Semarang, U. S., Dasar, S., \& Barat, K. S. (2022). Proceeding Sendiu 2021 Pendampingan Pembelajaran Luring Di Awal Masa New Normal Pada Paud Al Ikhlas Salman Kelurahan Salamanmloyo. 978-979.

Isnainia, \& Na'imah. (2020). Faktor yang Mempengaruhi Perkembangan Anak Usia Dini. Jurnal Pelita PAUD, 4(2), 197-207. https://doi.org/10.33222/pelitapaud.v4i2.968.

Istiqomah, L. (2017). Dinamika Perubahan Kurikulum: Kebijakan Perubahan Kurikulum 2013 PAUD. Golden Age: Jurnal Ilmiah Tumbuh Kembang Anak Usia Dini, 1(1), 39-52. https://doi.org/10.14421/iga.2016.11-04.

Kemdikbud. (2020). Panduan Penyelenggaraan Pembelajaran di Masa Pandemi COVID-19. Kemendikbud, 2019, https://www.kemdikbud.go.id/main/blog/2020/06/buku-saku-panduanpembelajaran-di-masa-pandemi-covid19.

Kemendikbud. (2021). Buku Saku Pembelajaran Di Masa Pandemi Coronavirus Disease 2019. 2019, 1-58. https://www.kemdikbud.go.id/main/files/download/8b4ebf61f4035e5. 
Kumalasari, P. I., \& Sugito, S. (2020). The Role of Student's Parent in Shaping Home Learning Environment (HLE) for Early Childhood. Jurnal Obsesi : Jurnal Pendidikan Anak Usia Dini, 5(2), 1521-1535. https:/ / doi.org/10.31004/obsesi.v5i2.881.

Margareta, N. (2020). Analisis Keterampilan Berbicara Siswa Pada Tema 6 Energi Dan Perubahannya Subtema 1 Sumber Nency Margareta Analysis Of Student Speaking Skills In The Theme 6 Energy And Its Changes In Subtema 1 Energy Sources Class 3 Sd Negeri 2 Bangoan. E-Journal Pembelajaran Inovasi, Jurnal Ilmiah Pendidikan Dasar, 8(9), 121-131.

Matondang, C. E. H. (2019). Analisis gangguan berbicara anak cadel (kajian pada perspektif psikologi dan neurologi). Jurnal Pendidikan Bahasa Dan Sastra Indonesia, 3(2), 49-59.

Monica, M. A., \& Yaswinda, Y. (2021). Analisis Implementasi Kurikulum 2013 PAUD di Masa Pandemi Covid-19 di Indonesia. Jurnal Basicedu, 5(2), 643-653. https://doi.org/10.31004/basicedu.v5i2.781.

Murti, S., \& Heryanto, H. (2020). The relevance of learning achievement as a predictor of empathy behavior in SMA Negeri 5 Samarinda. Jurnal Ilmiah Wahana Pendidikan, 6(3), 295-307. https:// doi.org/10.5281/zenodo.3960163.

Nahdi, K., Ramdhani, S., Yuliatin, R. R., \& Hadi, Y. A. (2020). Implementasi Pembelajaran pada Masa Lockdown bagi Lembaga PAUD di Kabupaten Lombok Timur. Jurnal Obsesi : $\begin{array}{lllll}\text { Jurnal Pendidikan Anak Usia Dini, } & 177 .\end{array}$ https://doi.org/10.31004/obsesi.v5i1.529.

Ningrum, E. O., Sakohara, S., \& Gotoh, T. Suprapto, and Humaidah, N., 2019, The effect of cation and anion species on the transition and adsorption behaviors of thermosensitive sulfobetaine gel-based adsorbent. Int. J. Technol, 10(3), 443-452. https:// doi.org/10.29313/mimbar.v34i2.3668.

Pradinda, R., Dwi, F., \& Santana, T. (2020). Meningkatkan Keterampilan Berbicara Pada Anak. Jurnal Ceria (Cerdas Energik Responsif Inovatif Adaptif), 3(5), 411-417.

Pratesi, P. C. (2018) “Persepsi Guru Paud Terhadap Faktor-Faktor Yang Menghambat Dalam Melaksanakan Pembelajaran Di Paud Se-Kecamatan Ujan Mas Kabupaten Kepahiang", Raudhatul Athfal: Jurnal Pendidikan Islam Anak Usia Dini, 2(2), pp. 72-79. doi: https:// doi.org/10.19109/ra.v2i2.2849.

Purwanita, Y., Riyanto, Y., \& Suyanto, T. (2019). The Influence of Multimedia Assisted Inquiry Learning Methods on My Heroes Theme of Critical Thinking Skills and Learning Outcomes of Class IV Students ofElementary School. International Journal of Scientific $\begin{array}{llll}\text { and Research Publications (IJSRP), 9(7), p9169. } & \end{array}$ https:// doi.org/10.29322/IJSRP.9.07.2019.p9169.

Ridwan, A., Siswanto, E., Susanto, S., Setianto, Y. C., Muslimin, S., \& Arifin, M. Z. (2021). Penerapan Metode Belajar Daring untuk Pendidikan Anak Usia Dini S/D Pendidikan Dasar pada Masa Pandemi Covid-19. Jurnal Abdimas Berdaya : Jurnal Pembelajaran, $\begin{array}{llll}\text { Pemberdayaan Dan Pengabdian } 30 . & \text { Masyarakat, }\end{array}$ https://doi.org/10.30736/jab.v4i01.86.

Ruiyat, S. A., Yufiarti, Y., \& Karnadi, K. (2019). Peningkatan Keterampilan Berbicara dengan Bercerita Menggunakan Komik Elektronik Tematik. Jurnal Obsesi : Jurnal Pendidikan Anak Usia Dini, 3(2), 518https://doi.org/10.31004/obsesi.v3i2.256.

Shaleh, M., \& Anhusadar, L. (2021). Kesiapan Lembaga PAUD dalam Pembelajaran Tatap Muka pada New Normal. Jurnal Obsesi : Jurnal Pendidikan Anak Usia Dini, 5(2), 21582167. https://doi.org/10.31004/obsesi.v5i2.1139.

Shofa, M. F., \& Suparno, S. (2014). Peningkatan Keterampilan Berbicara Anak Usia Dini Melalui Permainan Sandiwara Boneka. Jurnal Pendidikan Dan Pemberdayaan Masyarakat, 1(2), 209. https:// doi.org/10.21831/jppm.v1i2.2690.

Sudrajat, C. J., Agustin, M., Kurniawati, L., \& Karsa, D. (2020). Strategi Kepala TK dalam Meningkatkan Mutu Pendidikan pada Masa Pandemi Covid 19. Jurnal Obsesi : Jurnal Pendidikan Anak Usia Dini, 5(1), 508. https://doi.org/10.31004/obsesi.v5i1.582. 
Sugiyono. (2018). Metode Penelitian Pendidikan (ke-27). Alfabeta.

Suningsih, A. (2018). Mengapa Skenario Pembelajaran Perlu Pendidikan Karakter? International Journal of Community Service Learning, 2(1), 34. https://doi.org/10.23887/ijcsl.v2i1.12889.

Suryana, D. (2017). Pembelajaran Tematik Terpadu Berbasis Pendekatan Saintifik Di Taman Kanak-Kanak. Jurnal Pendidikan Usia Dini, $11(1), 67-82$. https://doi.org/10.21009/JPUD.111.05.

Variansi, V., -, E., \& Harsono, N. (2018). Mengembangkan Keterampilan Berbicara Pada Anak Usia Dini Melalui Metode Sosiodrama. Cakrawala Dini: Jurnal Pendidikan Anak Usia Dini, 7(1). https://doi.org/10.17509/cd.v7i1.10547.

Wood, E., \& Hedges, H. (2016). Curriculum in early childhood education: critical questions about content, coherence, and control. Curriculum Journal, 27(3), 387-405. https://doi.org/10.1080/09585176.2015.1129981.

Zahro, I. F. (2015). Penilaian dalam Pembelajaran Anak Usia Dini. Tunas Siliwangi, 1(1), 92111. https:// doi.org/10.22460/ts.v1i1p92-111.95. 